\title{
INTEGRATION OF SUSTAINABILITY STRATEGIES IN ARCHITECTURAL EDUCATION TOWARDS THE ACHIEVEMENT OF THE COMPREHENSIVE QUALITY CONTROL
}

\author{
Nisreen Samy Ahmed Abdeen \\ Lecturer in Architectural Department, Heliopolis University (HU)
}

\begin{abstract}
:
This study attempts to integrate the comprehensive sustainability in architectural education, by using modern techniques to preserve our environment. This paper shows the progress in upraising the architect qualifications in sustainability, and how to apply it in their projects. Throughout our survey on the principles of learning, and teaching architectural process, the researchers find out a great shortage in applying comprehensive sustainability in order to reach it to its ideal form. By using a questionnaire form to be applied on teaching members, students of final years and the supervisors to reveal the sustainability awareness in a way to be integrated by the built environment.

This paper focuses on the Priority of Sustainability in architectural education, and how we can reach it to be existed. The researchers aim to apply framework for assessing the student learning objectives to approach to a clear transition between the education and cultural assessment.

It addresses the circumstances of our educational architectural principles as a primary target for undergraduate students. The Intended learning outcome has to include the research objectives, and the structure of the educational architectural program, classifying its criteria to assess it to reach to the main source of problem.
\end{abstract}

\section{Keywords:}

Sustainability, Architectural education strategies, comprehensive control, educational architectural program.

\section{Methodology}

The research methodology is based on having a comparative analysis of architectural educational strategies nationally, and internationally by analysing, synthesis, to evaluate it to be an ideal strategy that can be applied on latest two years. The basic role of general specifications of educational and learning process, how to accomplish by inclusiveness, flexibility, development, and difference in students' qualifications.

\section{1-Introduction:}

This paper focused on identifying the different types of existed architectural education that deals with the student, or the Tutor, or both of them. The ILOS types are direct teaching strategy, cooperative learning strategy (active learning), brainstorming strategy, self-learning strategy, project-based learning, and feedback strategy.

The used strategies build upon specific criteria of each curriculum, accomplishing its educational learning goals in complementary way. There is a great difference between traditional educational learning strategies and targeted learning outcomes of the research program goals. The goals of each strategy that is more effectively in our 
existed architectural education, based on the research assuming, in order to verify its effectiveness.

\section{1-1-The research outputs based on main items:}

1-1-1-Knowledge and understanding:

Upon completing this course, the student should be able to:

- Analyse clearly the characteristic features of the architecture of each period.

- Describe visualization the main factors which brought about changes in each style.

1-1-2-Intellectual skills

Upon completing this course, the student should be able to:

Create the ability to analyse the political, economic, social factors impact on building through history.

Reach to the ability to understand the difference between "the simple building" \& "the complex building" in components, materials\& style ... etc.

1-1-3-Professional and practical skills

Upon completing this course, the student should be able to:

Develop the students' skills in presenting their researches in front of many audiences.

Reach to discuss the architectural problems with a team logically.

1-1-4-General and transferable skills

Upon completing this course, the student should be able to:

Collaborate effectively multidisciplinary team.

search for information and engage in life- long self-learning discipline.

Place (national architectural accrediting board) in Egyptian architectural accrediting board, Architectural engineering program, Egyptian supreme council of universities, RIBA, AASTMT programs accredited by the supreme council of Egyptian architecture.

Defining the assessment process, strategies for educational outcome and blending it with sustainability techniques. This paper focuses on the Priority of Sustainability in architectural education, and how we can reach it to be existed.

The researchers aim to apply framework for assessing the student learning objectives to approach to a clear transition between the education and cultural assessment. It addresses the circumstances of our educational architectural principles as a primary target for undergraduate students. The Intended learning outcome has to include the research objectives, and the structure of the educational architectural program, classifying its criteria to assess it to reach to the main source of problem.

\section{1-2-Research problem:}

Program outcomes and course objectives in architectural education. Shortages in applying sustainability in all curriculums in an effective way. So, the first phase is preparing a strategic demand of sustainability to be applied to solve the community problems in taking it as case studies in subjects, to mingle the students to participate in fact life problems, and see their output impact reflected in life.

\section{2-Sustainable architectural Education in Egypt:}

The paper defines the main courses that needs sustainability in the curriculum. So, upgrading sustainable thinking is essential in, progressing our academic curriculum, such as NARS rules Which are 12 basic rules ,16\% in engineering sector, to match 
with the architectural goals in solving our environmental problems. This paper set aim is to be reach an effective pedagogical methodology for teaching sustainable architecture theory in a holistic manner, to be fully integrated into architecture education and practice.

\section{2-1-Measures of creativity}

Using the general planning and criteria assessment models in architecture education A proposed of learning outcomes in architectural education Case study.

\section{2-2-Missions of Education:}

Architecture and urbanism educational systems need constant updating to keep up with continuous technological advancements. The pedagogy of architecture and urbanism needs to bridge the gap between academia and practice, using innovative teaching methods and techniques.

So how to apply sustainability in architectural program, to achieve our goals in implementing sustainability in an ideal way in the given curriculums. So, we can find the theories of sustainability is applied in design projects afterwards. Sustainability has to be applied in a holistic way to maintain its continuity to protect the environment, and its society. (Raminez2006), (RIBA)2002. The research starts by defining the sustainability educational needs, its environmental awareness, how to design environmental buildings (kim,1998). So, it is preferable to start sustainability activities in the first years, practicing it by different educational methods.

- environmental awareness

- different methods of environmental buildings

- capability of designing sustainable building.

- Forming of education professional progress.

Throughout this, sustainability will be up to date, coping to the continuous technological studies. There must be inventive studies in sustainable teaching, suggesting all other alternative methods. (Ramirez 2006, Nguyen 1999, Elliot 2004) found that sustainability is an applying sustainable definitions in education in a practical way. Most of sustainable architectural education was elective courses regarding to the efficiency of energy saving. Where environmental designing is related to architectural design or technical studies. (Fowles 2003, Ramirez, Nguyen 1999).

The real difficulty is in merging sustainable methods in educational process, and research. (Fowles 2003, Ramirez, Ngueyen 1999, that show the sustainable methods, and its difficulty in merging it in educational process, as it has to be first based on analysis, reading, architectural programs, revising architectural educational program with sustainability. Verification of teaching efficiency throughout questionnaire submitted to both lecturer, students, to find out the reasons of shortage in applying it, to reach to a convenient theoretical approach.

\section{3- The goal of teaching architectural sustainability:}

To apply energy saving, respect of users, coping with climate, site (urban context), using natural resources, partial issues for architect program. So, to Preserve of natural 
resources, and upgrading building life style by solar energy, decreasing fuel allophonic acid, using renewable energy, decrease overcoming biological pollution. Where we can achieve designing buildings that can stands against any natural crisis (earthquake, wind, fire ), having great insurance for the user to provide comfort ,by using raw materials to apply sustainability ,recycling materials, and sea water.(EL Asimy 2010)Sustainability in our architectural education is a need, ( Alomonte ,2012), and our students in our future will be our engineers.

There should be several challenges in applying sustainable definitions and methods in our architectural education. The United Kingdom starts apply sustainability in education in a complementary way, managing between social, educational, economical, and spiritual themes sector with the environmental side. Schools of architecture focus with sustainability in united states, (Ramirez ,2006) stating that the holistic system in thinking, in a complementary way, linking between different majors, and social supply. The needed regulation's followed in taking decision regarding the teaching theme, inserting morals in taking decision, to reflect our humanity decisions by sustainable way to create an ideal architect. Instructions followed to reach to an ideal architectural education. (Kim ,1998), (Altamonte ,2012). Methods, entrances to include sustainable definition in architectural programs.

\section{4-Planning methodology}

The methodology applied in merging between Design curriculum, environmental curriculum, to be working parallel altogether in a separate way, inserting all definitions of sustainability, theoretical lectures in design studio. Where it is evaluated separately. There are lots of opposites in having the repetition of these instructions and design.

\section{4-1- Partial merge skeleton:}

Environmental design is used to link between design curriculum and main majors within definitions, circulation, to discover all its rules.

\section{4-2- Holistic skeleton:}

Practical major is the design, where applied all in different majors. It plays the main basic rule in upgrading sustainable projects within new needed resources, to participate in it.

\section{4-3 -Teaching staff:}

Urban design, statistics study to take opinion and to focus on decision. Taking climate in the first stage, where bigger percentage of the sample represents the thermal comfort definition, to cope with the site. To let design cope with the traditions, morals for the users. The curriculum, sustainability, environment control, first stage, students apply sustainability definitions. Technologies curriculum, it has to reflect sustainability, and we have shortage in finding alternatives for having the supplying techniques for sustainability. Compatibility programs for serving the sustainable design, that plays a great part in forming the ideal model with computer, analysing it teaching to products that has the best alternate solutions. 


\section{4-4- Planning linear hierarchy:}

The research is aiming to let the design curriculum, environmental curriculum, has to be working in a parallel way together in a separate way, inserting all definitions of sustainability. Theoretical approach of sustainability has to be applied in design studio, evaluating it separately through instructions. These instructions have lots of Partial hierarchy scale: environmental design is used to link between design curriculum, other main majors within definitions, to discover rules.

\section{4-5-Holistic hierarchy:}

practical major is applied in design, where it is a main basic rule in upgrading projects, within new needed resources. Merging sustainability in all majors.

- Discovery and awareness: by letting students participate in suggesting solutions and alternatives for the constrains facing it.

- understanding and action: apply what the students had studied, to discover the rule of sustainability, analyse the constrains, and finding alternate solution.

- progress targeted scale: can be applied in the first year of college, where specifying sustainability in different majors, to reflect its vision in implementing sustainability in architectural education.

- self-learning

\section{4-6 -Education:}

Table (1) shows the educational phases to apply sustainability in the given Instructions followed to reach ideal architectural education (kim,1998), (Altomonate 2012), methods and entrances to include sustainable definition in architectural programs

\begin{tabular}{|l|l|l|}
\hline Deep stage & \multicolumn{1}{|c|}{ Apply stage } & Classification stage \\
\hline $\begin{array}{l}\text { Different majors defending } \\
\text { on the research to discover } \\
\text { the students in } \\
\text { architectural depending on } \\
\text { the researches }\end{array}$ & $\begin{array}{l}\text { Apply in design } \\
\text { definitions, in deal } \\
\text { based on research. }\end{array}$ & $\begin{array}{l}\text { Merge sustainability in } \\
\text { architectural theoretical } \\
\text { lectures, encouraging } \\
\text { student in engaging them } \\
\text { in lots of activities. }\end{array}$ \\
\hline $\begin{array}{l}\text { Relate the definitions and } \\
\text { apply the progress and } \\
\text { specification. }\end{array}$ & $\begin{array}{l}\text { Encourage students in } \\
\text { analysing definitions, } \\
\text { improving the authority of } \\
\text { projects. }\end{array}$ & $\begin{array}{l}\text { Challenge and upgrade } \\
\text { students in their } \\
\text { knowledge. } \\
\text { Entering sustainability in } \\
\text { all courses to save the } \\
\text { humanity in our studies. } \\
\text { - Success in environmental } \\
\text { education } \\
\text { student show the } \\
\text { educational process }\end{array}$ \\
\hline Education has to cope with & Suggest strategies and new & \begin{tabular}{l} 
Student follow the updated \\
\hline
\end{tabular}
\end{tabular}




\begin{tabular}{|l|l|l|}
\hline job market & solutions educational \\
\hline $\begin{array}{l}\text { Support different majors } \\
\text { and connected together }\end{array}$ & $\begin{array}{l}\text { Increase the design } \\
\text { process as a research and } \\
\text { analysis }\end{array}$ & $\begin{array}{l}\text { Student should focus on } \\
\text { sustainable definitions }\end{array}$ \\
\hline $\begin{array}{l}\text { Apply sustainability by by } \\
\text { students in making } \\
\text { progress in design }\end{array}$ & $\begin{array}{l}\text { Analysis applied by } \\
\text { students, related to } \\
\text { context. }\end{array}$ & $\begin{array}{l}\text { Relate sustainability } \\
\text { definitions in discussions } \\
\text { with students }\end{array}$ \\
\hline $\begin{array}{l}\text { Participation of students in } \\
\text { sustainability to upgrade } \\
\text { their own skills }\end{array}$ & $\begin{array}{l}\text { Apply the theories } \\
\text { obtained by sustainability }\end{array}$ & $\begin{array}{l}\text { Share students in } \\
\text { educations by taking their } \\
\text { opinions and knowing their } \\
\text { sills by questionnaire }\end{array}$ \\
\hline & $\begin{array}{l}\text { Suggested solutions by } \\
\text { students in their design }\end{array}$ & \\
\hline
\end{tabular}

\subsection{Holistic or system thinking}

Upgrading sustainability to the architectural programs:

4-7-1-Linear hierarchy: Managing all design, all the related curriculum related to environment. The students study it theoretically in design studios, evaluating it separately, building too much rules related to sustainability, or it may oppose to the design process.

4-7-2-Partial merging hierarchy: Teaching part of environment design, linking between design and basic rules. Despite it teaches separately, but it can be linked by the curriculums through definitions, to discover its tools.

4-7-3-holistic merge hierarchy: Design is a space for applying all theories and studies. Where the design plays a central rule collecting all theoretical definitions needed by sustainability. (for the progress of projects, it needed all factors, that coordinates between all lecturers.

5-Repetitive hierarchy: Instead of linking the linear process, it depends on a linked chain, and linked phases, it needs efficiency obtained from the next process.

- In each stage, there is a deep thinking, upgrading the discovery capability from different sources, suggesting ideal models.

- Design Environmental studies, design studios coping with all the curriculum needed.

- choosing the needed curriculum, depends upon choosing different choices, within different grades, different majors, and how the student merge it all in the programs, relating to the rules of sustainability.

- Evaluating the linear entrances, where it offers flexibility, providing sustainability, from different point of views, showing the hierarchy of architectural sustainability.

- The architectural design, is the sustainable core in architecture" subject. education. The studio itself can be organised in a number of ways that could to enhance learning experience outcomes. Throughout time interval the architecture establishing techniques changes. For 
example, the studio/ atelier system can be articulated as "Units", "Project Groups", "Work Bases", "Blocks", "Subject Groups", "Vertical Studios", etc., where it can be established in years or "Parts" sequences.

6-Case study: comparison between MSA, sustainable HU, and AUC university in accomplishing sustainable in architectural courses.

Measure the integrated sustainable applied in which year percentage credit. The first stage of architectural education should not offer early specializations as it can compromise the expected outcome of that education. Specialization should not be introduced until the student has achieved a basic first stage architectural education

\section{6-1- Sustainable architecture design In MSA university (Greenwich university), NARS part 1}

\section{- Key Legend}

\section{Elective courses}

Environmental courses

Basic courses

Design courses

Table (2) shows Sustainable architecture courses applied in HU university (Altomonte ,2012)

\begin{tabular}{|c|c|c|c|c|}
\hline $\begin{array}{l}\text { Linear } \\
\text { planning }\end{array}$ & Partial merge & $\begin{array}{l}\text { Holistic } \\
\text { merge }\end{array}$ & $\begin{array}{l}\text { Repetitive } \\
\text { frame }\end{array}$ & Elective courses \\
\hline $\begin{array}{l}\text { General } \\
\text { First Year }\end{array}$ & $\begin{array}{l}\text { Year } 1,2 \\
\text { Second year }\end{array}$ & $\begin{array}{l}\text { Year 5, } \\
\text { Year 3, }\end{array}$ & & \\
\hline $\begin{array}{l}\text { Year } \\
\text { Architectural } \\
\text { design } \\
\text { Investigation an } \\
\text { proposition } \\
\text { credits) }\end{array}$ & $\begin{array}{l}\text { Year 2: } \\
\text { compulsor } \\
\text { module }\end{array}$ & t is a & $\begin{array}{l}\text { : Theory of } \\
\text { ability }\end{array}$ & $\begin{array}{l}\text { Year 4: ASE 462 } \\
\text { Housing }\end{array}$ \\
\hline $\begin{array}{l}\text { Cultural contex } \\
\text { of architecture (1 } \\
\text { credits), }\end{array}$ & $\begin{array}{l}\text { Contempor } \\
\text { theories } \\
\text { architecture } \\
\text { credits) }\end{array}$ & $\begin{array}{r}\text { of } \\
(15\end{array}$ & $\begin{array}{lr}\text { S } & (1.5 \\
k) & \\
\text { tal } & \text { class } \\
& \text { hours }\end{array}$ & $\begin{array}{l}\text { Studios } 4.5 \text { hrs /week, } \\
\text { Total class contact hrs } \\
84 \mathrm{hrs} / \text { semester, } \\
\text { Total self-study hours }\end{array}$ \\
\hline
\end{tabular}




\begin{tabular}{|c|c|c|c|}
\hline & & $\begin{array}{l}\text { (105hrs/semester) } \\
\text {, Total self-study } \\
\text { hours ( } 75 \\
\text { hrs/semester), } \\
\text { Total study hours } \\
\text { (180 hrs/semester) }\end{array}$ & $\begin{array}{l}\text { (60 hrs/semester, } \\
\text { Total study hours (144 } \\
\text { hrs /semester) }\end{array}$ \\
\hline $\begin{array}{l}\text { Architecture } \\
\text { design } \\
\text { (experimentation } \\
\text { and } \\
\text { communication) } \\
\text { (30 credits) }\end{array}$ & $\begin{array}{l}\text { Architectural } \\
\text { design } \\
\text { exploration } \\
\text { proposition } \\
\text { credits) }\end{array}$ & $\begin{array}{l}\text { ASE } 361 \text { Studios } \\
\text { (6 hrs/week) } \\
\text { Lectures } \\
\text { hrs/week, Tutorials } \\
1.5 \text { hrs/week, } \\
\text { Total class contact } \\
\text { hours } \\
\text { hrs/semester } \\
\text { Total self-study } \\
\text { hours } \\
\text { hrs/semester), } \\
\text { Total study hours } \\
\text { (108 hrs/semester) }\end{array}$ & $\begin{array}{l}\text { ASE } \\
\text { Architectural design } \\
\text { V, VI, Level:4 Credit } \\
\text { hours (5hrs) } \\
\text { architectural design I, } \\
\text { II, III, IIII (4 credit), } \\
\text { Lectures } 1.5 \mathrm{hrs} / \text { week }\end{array}$ \\
\hline $\begin{array}{l}\text { Architectural } \\
\text { design technology } \\
\text { I ( } 15 \text { credit })\end{array}$ & $\begin{array}{ll}\text { Architecture } & \\
\text { design } & 2: \\
\text { resolution } & (30 \\
\text { credits }) & \end{array}$ & $\begin{array}{lr}\begin{array}{l}\text { Year 3: } \\
\text { urban }\end{array} & \begin{array}{r}\text { ASE } \\
\text { planning }\end{array} \\
\text { and design } \\
\text { Credit hrs }\end{array}$ & \\
\hline $\begin{array}{l}\text { Landscape } \\
\text { technology } \\
\text { credits })\end{array}$ & $\begin{array}{l}\text { Introducing } \\
\text { architecture and } \\
\text { landscape practice }\end{array}$ & $\begin{array}{l}\text { Year 3: Technical } \\
\text { service system1 } \\
\text { Lecture } \quad 3\end{array}$ & \\
\hline
\end{tabular}




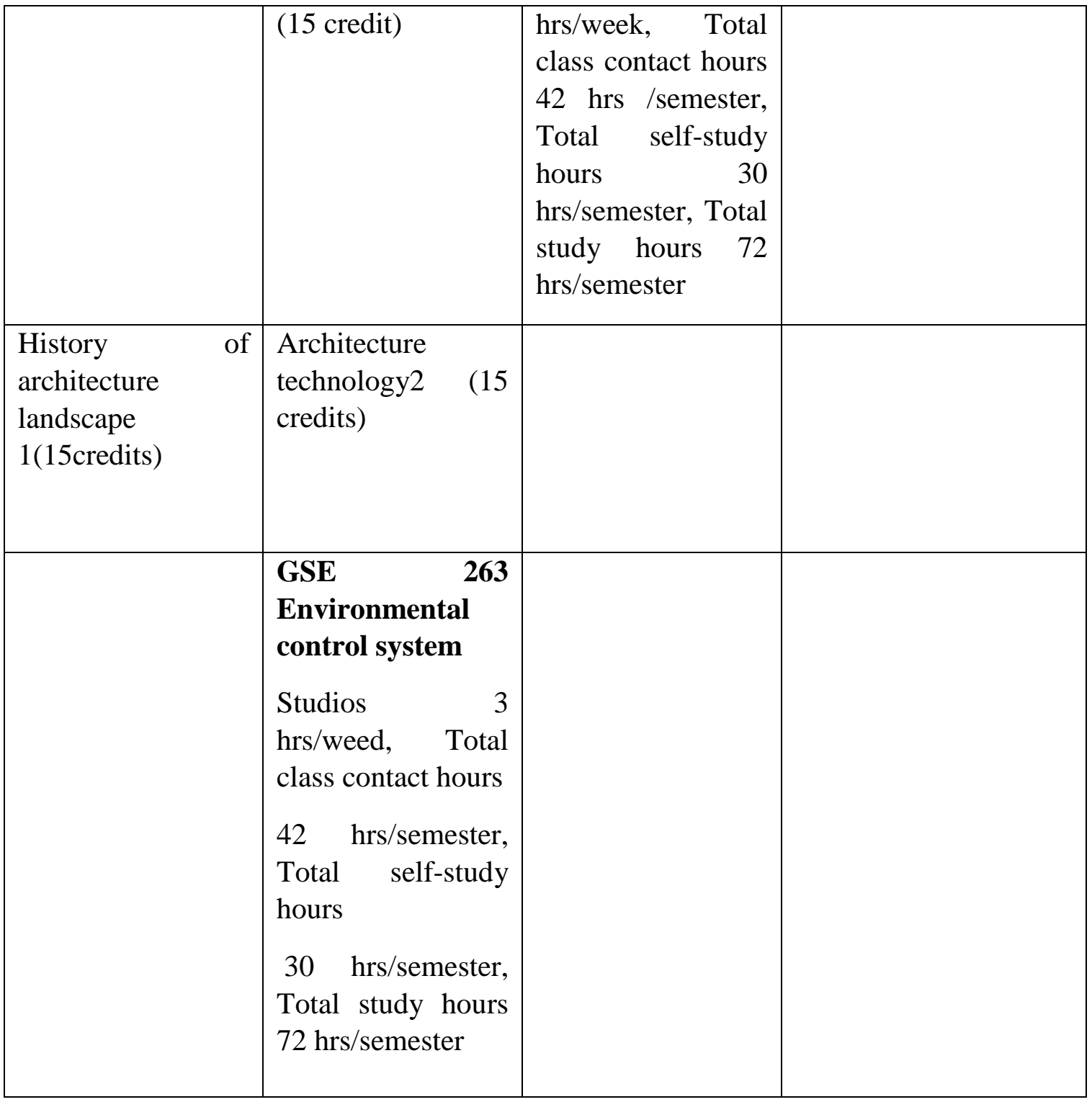

\section{6-2-Sustainable architecture design In HU university}

tive courses

Environmental courses

Basic courses

Green Design courses

Table (3) shows Sustainable architecture courses applied in MSA university (Greenwich university), NARS part 1 , (Altomonte ,2012)

\begin{tabular}{|l|l|l|l|l|}
\hline $\begin{array}{l}\text { Linear } \\
\text { Planning }\end{array}$ & Partial Merge & $\begin{array}{l}\text { Holistic } \\
\text { Merge }\end{array}$ & $\begin{array}{l}\text { Repetitive } \\
\text { Frame }\end{array}$ & Elective Courses \\
\hline & & & & \\
\hline
\end{tabular}




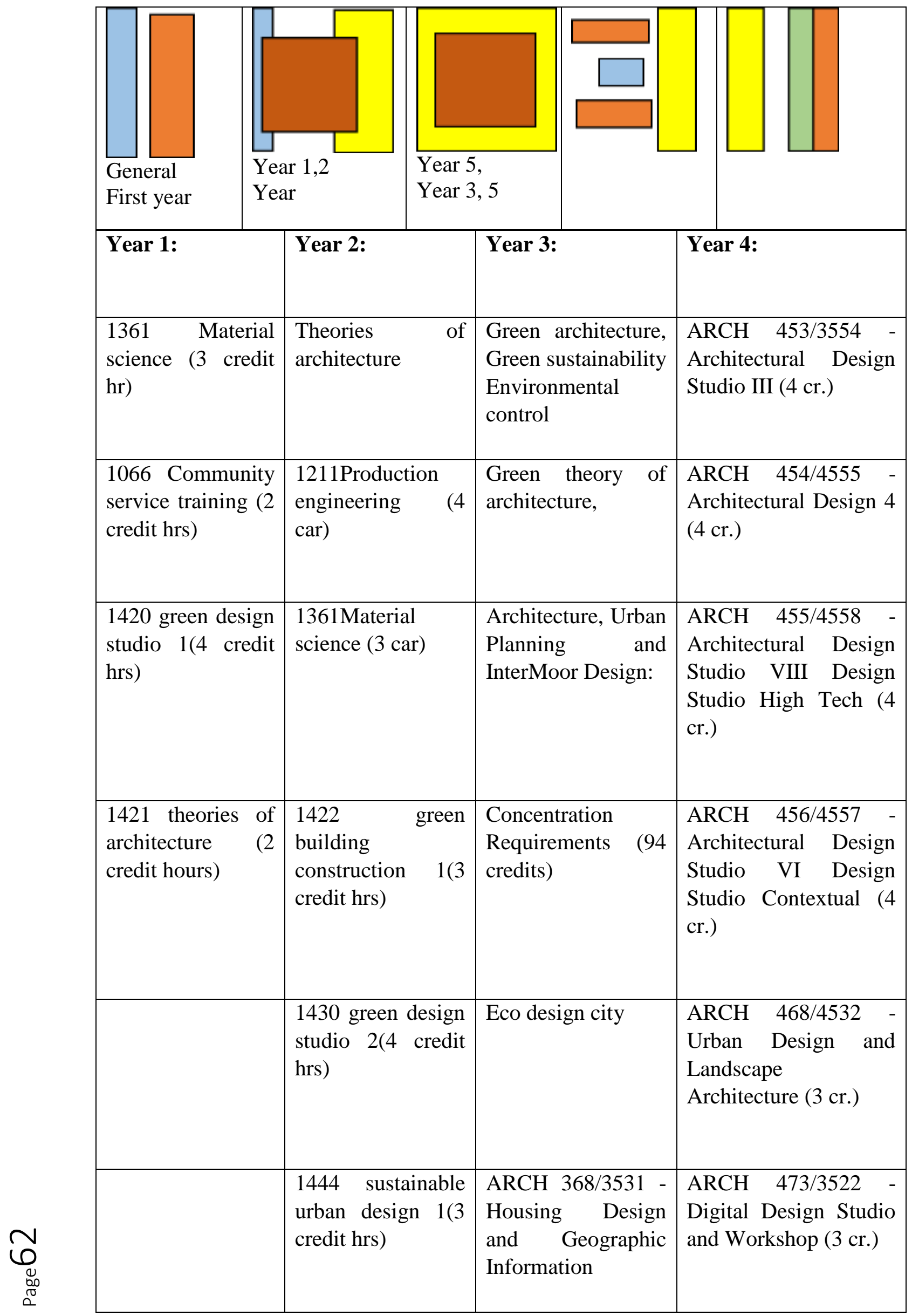




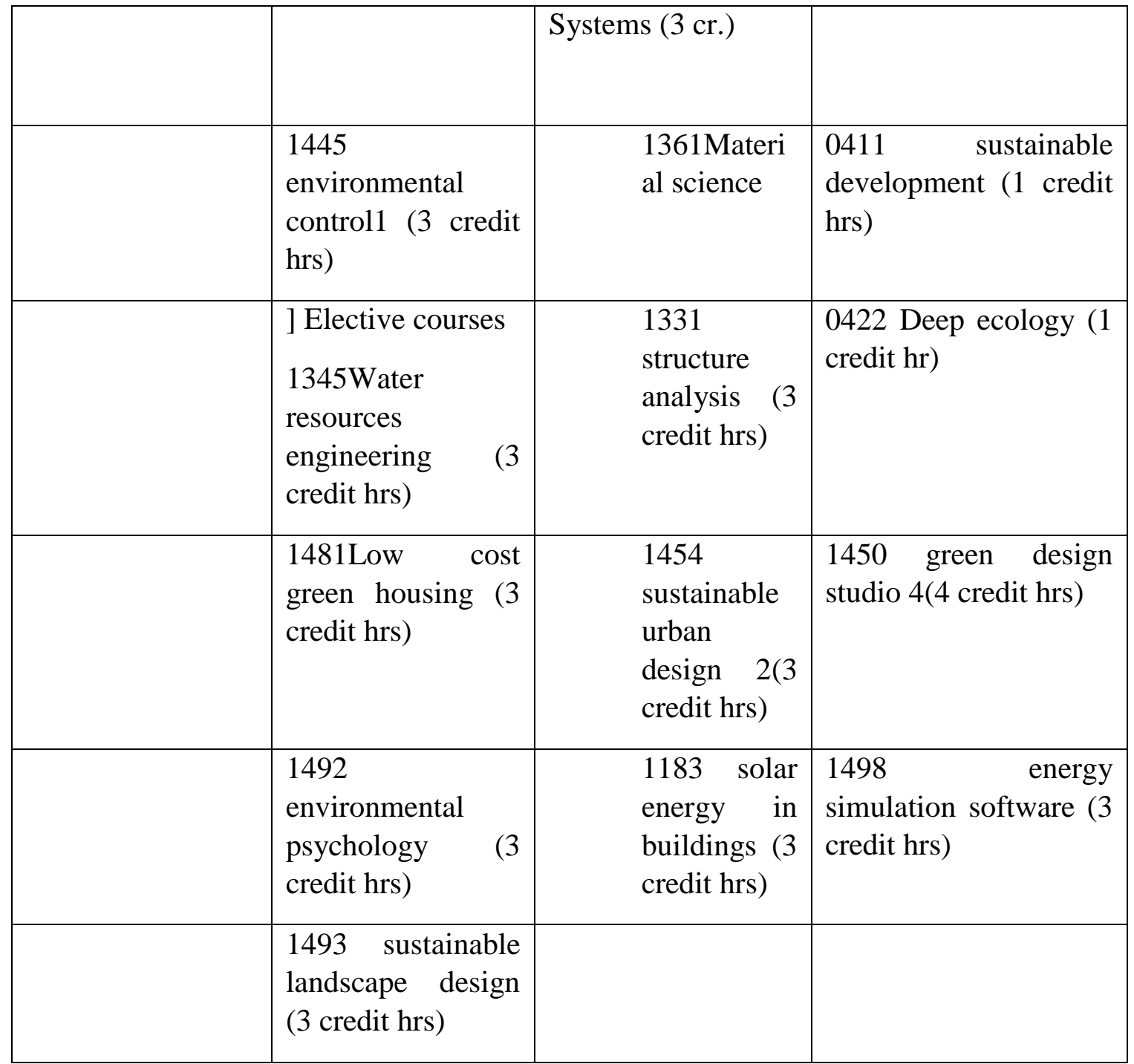

\section{6-3- Sustainable architecture design in AUC University}

\section{- Key Legend}

Elective courses

Environmental courses

Basic courses

Green Design courses

Table (4) shows Sustainable architecture applied in AUC university, Altomonte ,2012

\begin{tabular}{|l|l|l|l|l|}
\hline $\begin{array}{l}\text { Linear } \\
\text { Planning }\end{array}$ & Partial Merge & Holistic Merge & $\begin{array}{l}\text { Repetitive } \\
\text { Frame }\end{array}$ & Elective Courses \\
\hline & & & & \\
\hline
\end{tabular}




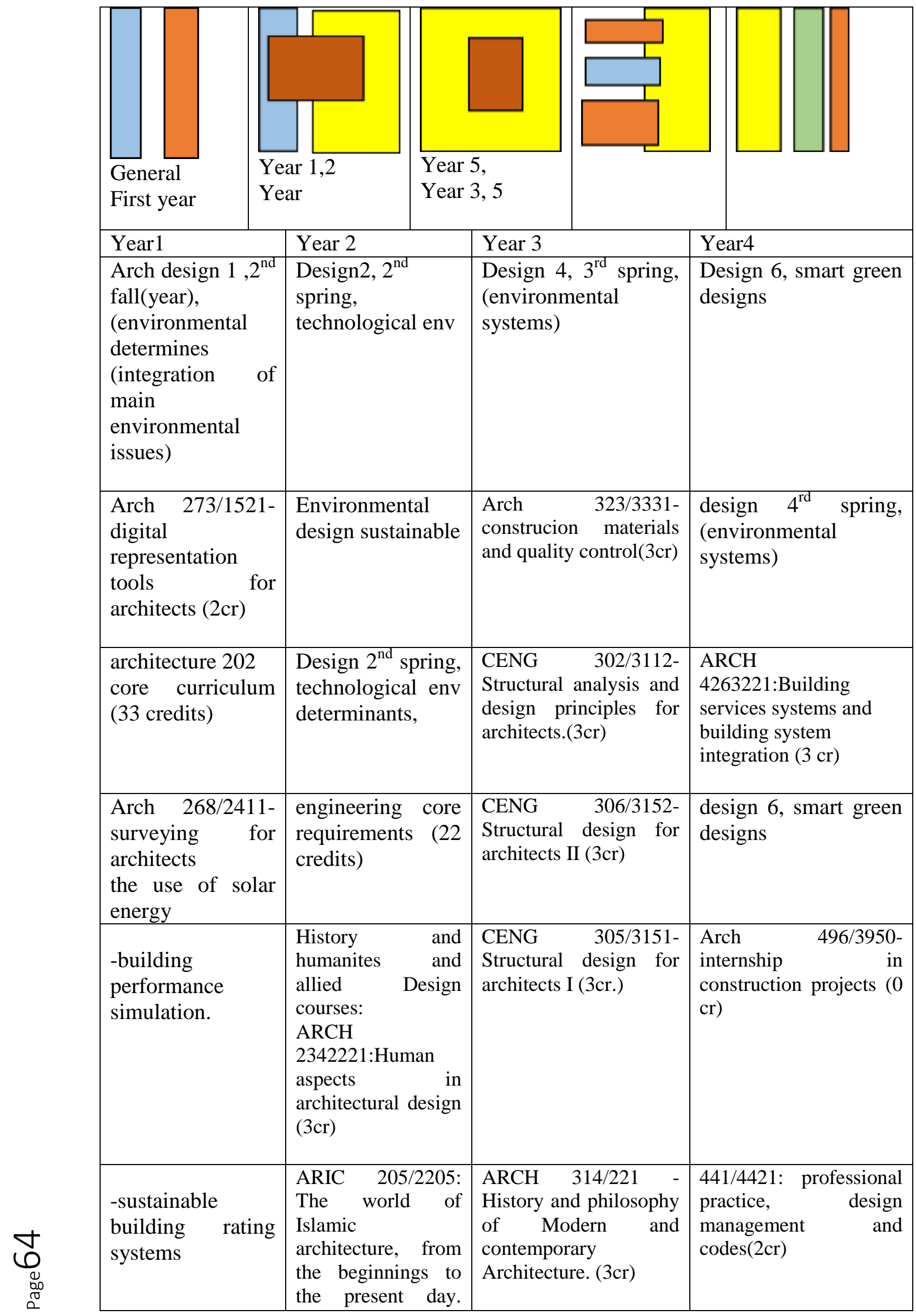




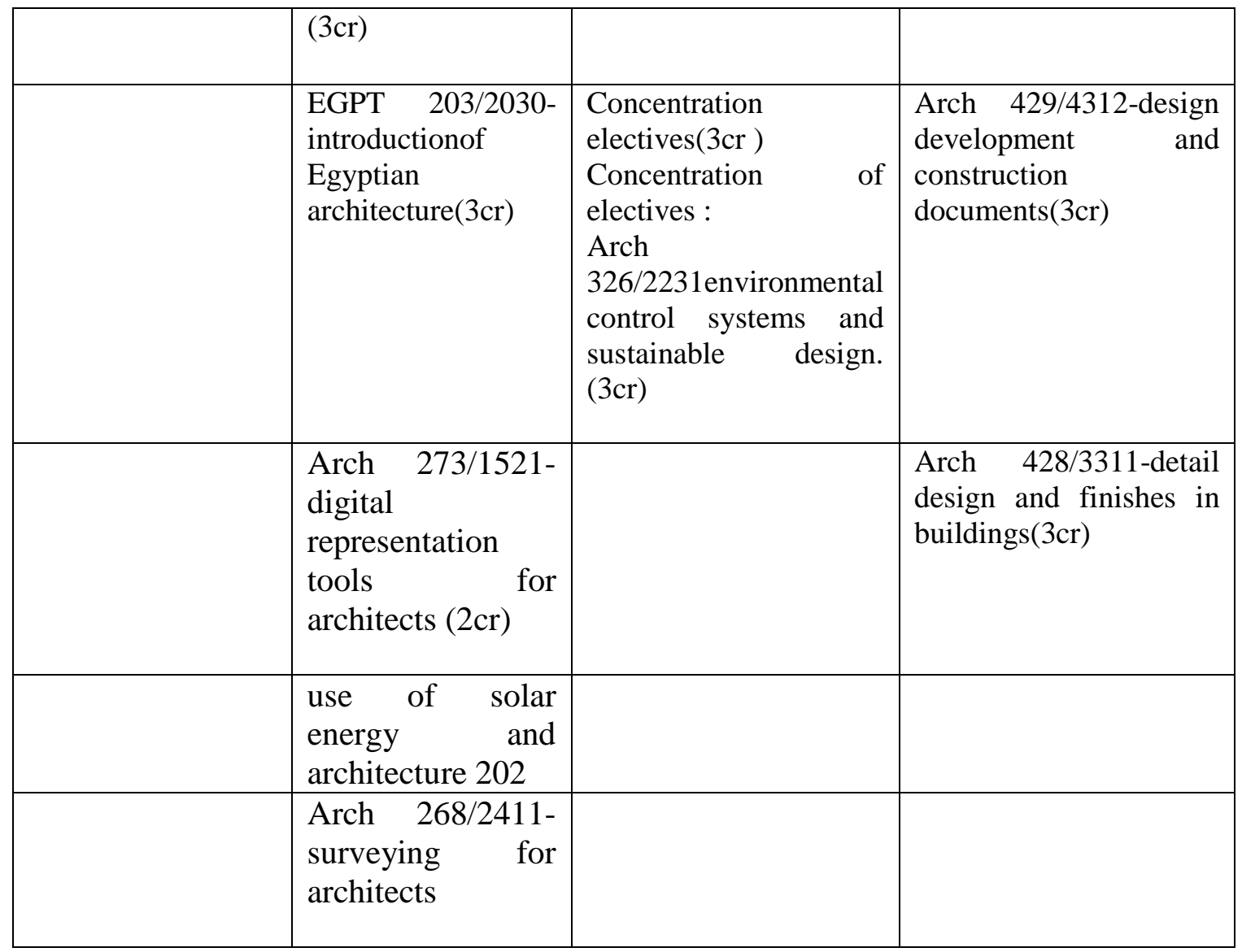

\section{6-4-UIA studies}

Table (5) shows sustainable architecture courses that should be applied according to UIA

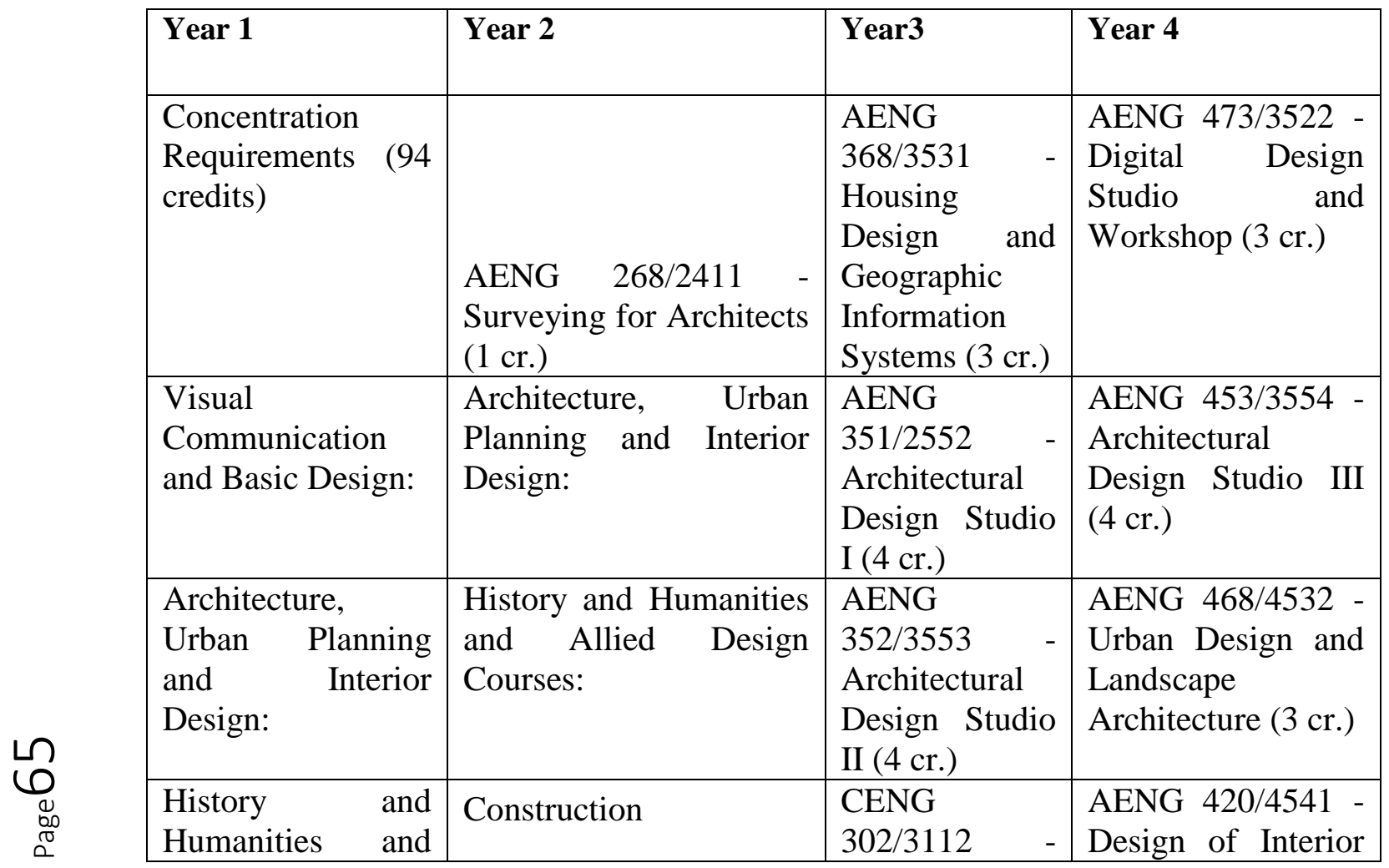




\begin{tabular}{|c|c|c|c|}
\hline $\begin{array}{ll}\text { Allied } & \text { Design } \\
\text { Courses: } & \end{array}$ & $\begin{array}{l}\text { Engineering and } \\
\text { Management: }\end{array}$ & $\begin{array}{l}\text { Structural } \\
\text { Analysis and } \\
\text { Design } \\
\text { Principles for } \\
\text { Architects }(3 \\
\text { cr.) }\end{array}$ & Spaces (3 cr.) \\
\hline $\begin{array}{l}\text { Construction } \\
\text { Engineering and } \\
\text { Management: }\end{array}$ & $\begin{array}{l}\text { Concentration } \\
\text { Requirements } \\
\text { credits) }\end{array}$ & $\begin{array}{l}\text { CENG } \\
305 / 3151 \quad- \\
\text { Structural } \\
\begin{array}{l}\text { Design for } \\
\text { Architects I (3 } \\
\text { cr.) }\end{array} \\
\end{array}$ & $\begin{array}{l}\text { AENG 454/4555 - } \\
\text { Architectural } \\
\text { Design Studio IV } \\
\text { (4 cr.) }\end{array}$ \\
\hline $\begin{array}{l}\text { Concentration } \\
\text { Requirements }(94 \\
\text { credits })\end{array}$ & $\begin{array}{l}\text { Visual Communication } \\
\text { and Basic Design: }\end{array}$ & & $\begin{array}{l}\text { AENG 455/4556 - } \\
\text { Architectural } \\
\text { Design Studio V (4 } \\
\text { cr.) }\end{array}$ \\
\hline $\begin{array}{l}\text { Visual } \\
\text { Communication } \\
\text { and Basic Design: }\end{array}$ & $\begin{array}{l}\text { CENG } 302 / 3112- \\
\text { Structural Analysis and } \\
\text { Design Principles for } \\
\text { Architects }(3 \mathrm{cr} .)\end{array}$ & & $\begin{array}{l}\text { AENG } 456 / 4557- \\
\text { Architectural } \\
\text { Design Studio VI } \\
(4 \text { cr.) }\end{array}$ \\
\hline $\begin{array}{l}\text { renewable energy } \\
\text { system } \\
\text { Indoor air quality } \\
\text { Economics of } \\
\text { green building }\end{array}$ & $\begin{array}{l}\text { CENG 305/3151 - } \\
\text { Structural Design for } \\
\text { Architects I (3 cr.) } \\
\end{array}$ & & $\begin{array}{l}\text { AENG 490/4980 - } \\
\text { Senior Project I ( } 2 \\
\text { cr.) }\end{array}$ \\
\hline $\begin{array}{l}\text { Visual Studies and } \\
\text { Design } \\
\text { Fundamentals } \\
\text { Urbanism and } \\
\text { Climate }\end{array}$ & $\begin{array}{l}\text { CENG } 446 / 4440- \\
\text { Techniques of Planning, } \\
\text { Scheduling and Control } \\
(3 \text { cr. })\end{array}$ & & $\begin{array}{l}\text { CENG 446/4440 - } \\
\text { Techniques of } \\
\text { Planning, } \\
\text { Scheduling and } \\
\text { Control }(3 \mathrm{cr} \text {.) } \\
\end{array}$ \\
\hline & $\begin{array}{lr}\text { CENG } 447 / 4450 & - \\
\text { Design, Modelling and } \\
\text { Simulation } \\
\text { Construction Systems (3 } \\
\text { cr.) }\end{array}$ & & $\begin{array}{l}\text { CENG 447/4450 - } \\
\text { Design, Modelling } \\
\text { and Simulation of } \\
\text { Construction } \\
\text { Systems }(3 \mathrm{cr} \text {.) }\end{array}$ \\
\hline & $\begin{array}{l}\text { CENG } 452 / 4158 \\
\text { Structural Systems and } \\
\text { Advanced Design }(3 \mathrm{cr} .)\end{array}$ & & $\begin{array}{l}\text { CENG 452/4158 - } \\
\text { Structural Systems } \\
\text { and Advanced } \\
\text { Design (3 cr.) }\end{array}$ \\
\hline & $\begin{array}{l}\text { CENG } 302 / 3112 \\
\text { Structural Analysis and }\end{array}$ & & $\begin{array}{l}\text { Concentration } \\
\text { Electives }\end{array}$ \\
\hline
\end{tabular}




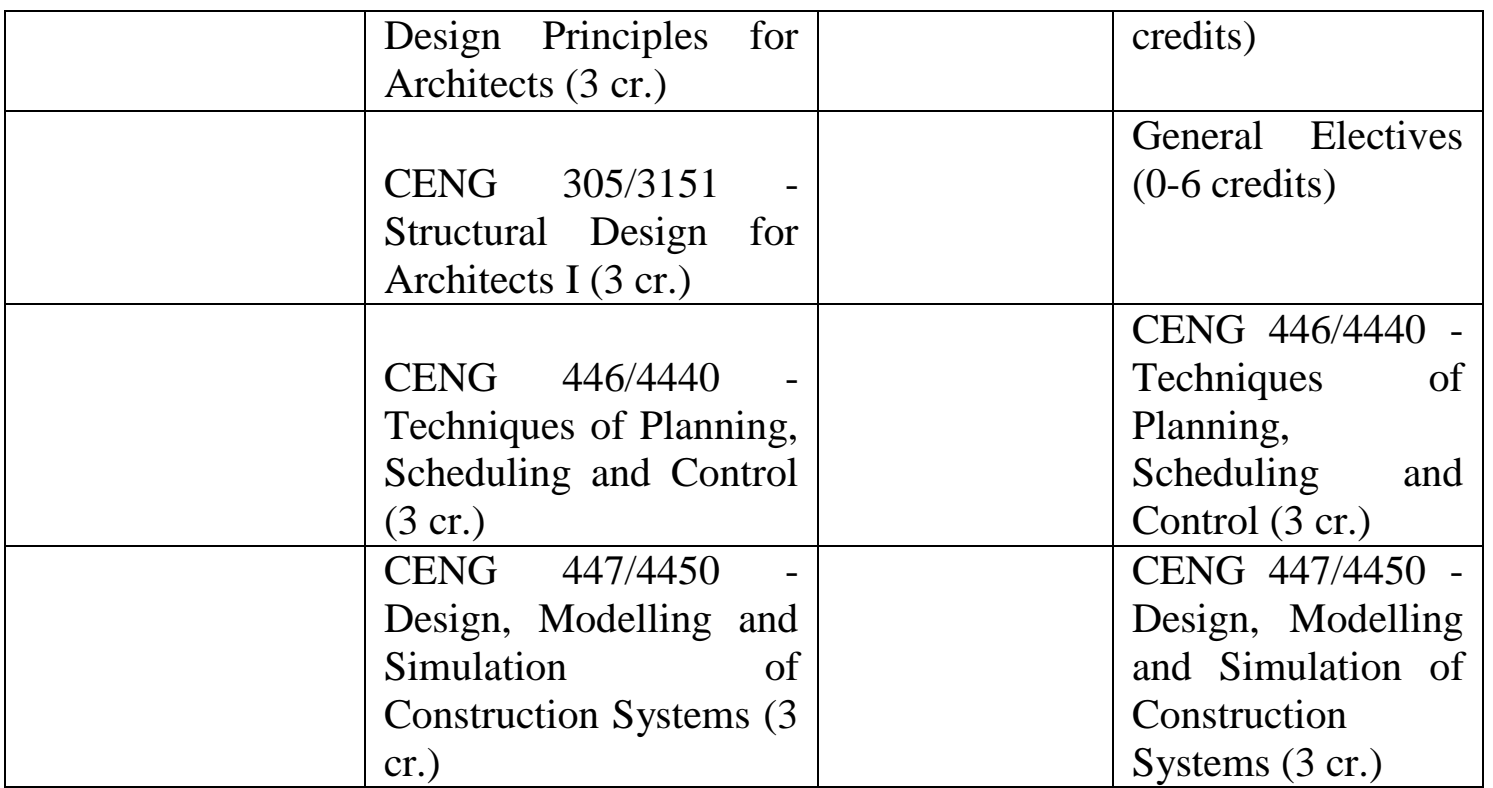

\section{6-4-1- UIA assessment :}

UNESCO -UIA vaildation system of architectural study programmes is comprised into two stages recognition, and renewal of recognition for assessing the criteria there are no eligibilty ,candidacy and preliminary stage in systems.

So reviews of programmes, overview of Unesco-UIA vaildationsin the citeria of education.and its duration of study.eligibity stage is considered to be for the whole five years, within 2 years professional practice experience.

Undergraduate universites in cairo teaching sustainable courses, ELgibilty ,as an intial validation of a study programme,candidcy and full recognition.

\section{6-4-2 Critical engagement in architectural sustainable education:}

It is as an effective issue to engage students from the field to apply it by our future vision method to encourage the students to change their perspectives. The students assess critically which information can build upon it the rest of information to receive critical effective ideas. From our survey we focused on the limitations facing sustainability to let it be independent educational. The obstacles facing sustainable architectural education: It identifies its historical value by its multiple interpretation.by applying basic sustainable principles in an integrated with the environment., Students engagement should be with multiple dimensions. Applying Swot analysis to verify the impact of sustainability in architectural courses in Applying pedagogical rules.

\section{6-4-3-International accreditation required by UIA credit rules}

Table (6) shows Sustainable architecture applied according to UIA assessment. (UIA, 2017). 


\begin{tabular}{|c|c|c|c|c|}
\hline $\begin{array}{l}\text { Student ID: ___ Adviser } \\
\text { Name: } \\
\text { Name:__ }\end{array}$ & \multicolumn{4}{|c|}{$\begin{array}{l}\text { CatLog: 2015-2016 Academic } \\
\text { Catalogue Program: Architectural } \\
\text { Engineering (B.S.) Minimum Credits } \\
\text { Required: }\end{array}$} \\
\hline \multicolumn{5}{|l|}{ Concentration Requirements (94 credits) } \\
\hline \multicolumn{5}{|l|}{ Visual Communication and Basic Design: } \\
\hline Course Name & & $\begin{array}{l}\text { Term } \\
\text { Taken }\end{array}$ & Grade & Gen Ed \\
\hline \multicolumn{5}{|l|}{$\begin{array}{l}\text { AENG 250/2512 - Foundations of 3-Dimensional } \\
\text { Design ( } 3 \mathrm{cr} .)\end{array}$} \\
\hline \multicolumn{5}{|l|}{$\begin{array}{l}\text { AENG } 251 / 2551 \text { - Introduction to Architectural } \\
\text { Design }(3 \mathrm{cr} .)\end{array}$} \\
\hline \multicolumn{5}{|l|}{ Architecture, Urban Planning and Interior Design: } \\
\hline Course Name & & $\begin{array}{l}\text { Term } \\
\text { Taken }\end{array}$ & Grade & Gen Ed \\
\hline \multicolumn{5}{|l|}{$\begin{array}{l}\text { Course Name } \\
\text { AENG 268/2411 - Surveying for Architects ( } 1 \mathrm{cr} \text {.) }\end{array}$} \\
\hline \multicolumn{5}{|l|}{ AENG 351/2552 - Architectural Design Studio I (4 cr.) } \\
\hline \multicolumn{5}{|l|}{$\begin{array}{l}\text { AENG 368/3531 - Housing Design and Geographic } \\
\text { Information Systems ( } 3 \text { cr.) }\end{array}$} \\
\hline \multicolumn{5}{|l|}{$\begin{array}{l}\text { AENG 352/3553 - Architectural Design Studio II (4 } \\
\text { cr.) }\end{array}$} \\
\hline \multicolumn{5}{|l|}{$\begin{array}{l}\text { AENG 453/3554 - Architectural Design Studio III ( } 4 \\
\text { cr.) }\end{array}$} \\
\hline \multicolumn{5}{|l|}{$\begin{array}{l}\text { AENG 468/4532 - Urban Design and Landscape } \\
\text { Architecture ( } 3 \text { cr.) }\end{array}$} \\
\hline \multicolumn{5}{|l|}{ AENG 420/4541 - Design of Interior Spaces (3 cr.) } \\
\hline \multicolumn{5}{|l|}{$\begin{array}{l}\text { AENG 454/4555 - Architectural Design Studio IV (4 } \\
\text { cr.) }\end{array}$} \\
\hline \multicolumn{5}{|l|}{$\begin{array}{l}\text { AENG 455/4556 - Architectural Design Studio V (4 } \\
\text { cr.) }\end{array}$} \\
\hline \multicolumn{5}{|l|}{$\begin{array}{l}\text { AENG 456/4557 - Architectural Design Studio VI (4 } \\
\text { cr.) }\end{array}$} \\
\hline \multicolumn{5}{|l|}{ History and Humanities and Allied Design Courses: } \\
\hline \multicolumn{5}{|l|}{$\begin{array}{l}\text { AENG } 234 / 2221 \text { - Human Aspects in Architectural } \\
\text { Design ( } 3 \text { cr.) }\end{array}$} \\
\hline \multicolumn{5}{|l|}{$\begin{array}{l}\text { ARIC } 205 / 2205 \text { - The World of Islamic Architecture, } \\
\text { from the Beginnings to the Present Day }(3 \mathrm{cr} \text {.) }\end{array}$} \\
\hline \multicolumn{5}{|l|}{$\begin{array}{l}\text { AENG 326/2231 - Environmental Control Systems } \\
\text { and Sustainable Design ( } 3 \mathrm{cr} .)\end{array}$} \\
\hline \multicolumn{5}{|l|}{$\begin{array}{l}\text { AENG 234/2221 - Human Aspects in Architectural } \\
\text { Design ( } 3 \text { cr.) }\end{array}$} \\
\hline \multicolumn{2}{|l|}{$\begin{array}{l}\text { ARIC } 205 / 2205 \text { - The World of Islamic Architecture, } \\
\text { from the Beginnings to the Present Day ( } 3 \mathrm{cr} \text {.) }\end{array}$} & & & \\
\hline \multicolumn{2}{|l|}{ AENG 326/2231 - Environmental Control Systems } & & & \\
\hline
\end{tabular}




\begin{tabular}{|c|c|c|c|}
\hline \multicolumn{4}{|l|}{ and Sustainable Design (3 cr.) } \\
\hline \multicolumn{4}{|l|}{$\begin{array}{l}\text { AENG 428/3311 - Detail Design and Finishes in } \\
\text { Buildings ( } 3 \mathrm{cr} \text {.) }\end{array}$} \\
\hline \multicolumn{4}{|l|}{$\begin{array}{l}\text { AENG 429/4312 - Design Development and } \\
\text { Construction Documents ( } 3 \text { cr.) }\end{array}$} \\
\hline \multicolumn{4}{|l|}{ Construction Engineering and Management: } \\
\hline Course Name & $\begin{array}{l}\text { Term } \\
\text { Taken }\end{array}$ & Grade & Gen Ed \\
\hline \multicolumn{4}{|l|}{$\begin{array}{l}\text { AENG 426/3321 - Building Service Systems and } \\
\text { Building Systems Integration ( } 3 \text { cr.) }\end{array}$} \\
\hline \multicolumn{4}{|l|}{$\begin{array}{l}\text { AENG 323/3331 - Construction Materials and Quality } \\
\text { Control (3 cr.) }\end{array}$} \\
\hline \multicolumn{4}{|l|}{$\begin{array}{l}\text { CENG 302/3112 - Structural Analysis and Design } \\
\text { Principles for Architects ( } 3 \text { cr.) }\end{array}$} \\
\hline \multicolumn{4}{|l|}{$\begin{array}{l}\text { CENG 305/3151 - Structural Design for Architects I ( } 3 \\
\text { cr.) }\end{array}$} \\
\hline \multicolumn{4}{|l|}{$\begin{array}{l}\text { CENG 306/3152 - Structural Design for Architects II } \\
\text { (3 cr.) }\end{array}$} \\
\hline \multicolumn{4}{|l|}{$\begin{array}{l}\text { CENG 423/4252 - Methods and Equipment for } \\
\text { Construction I ( } 3 \text { cr.) }\end{array}$} \\
\hline \multicolumn{4}{|l|}{$\begin{array}{l}\text { Concentration Electives ( } 3 \text { credits) } \\
\text { Students should take one course from the following: }\end{array}$} \\
\hline Course Name & $\begin{array}{l}\text { Term } \\
\text { Taken }\end{array}$ & Grade & Gen Ed \\
\hline \multicolumn{4}{|l|}{$\begin{array}{l}\text { CENG } 446 / 4440 \text { - Techniques of Planning, Scheduling } \\
\text { and Control }(3 \mathrm{cr} .)\end{array}$} \\
\hline \multicolumn{4}{|c|}{$\begin{array}{l}\text { CENG 447/4450 - Design, Modelling and Simulation } \\
\text { of Construction Systems ( } 3 \mathrm{cr} .)\end{array}$} \\
\hline \multicolumn{4}{|c|}{$\begin{array}{l}\text { CENG 452/4158 - Structural Systems and Advanced Design ( } 3 \text { cr.) CENG 494/4911 - } \\
\text { Selected Topics in Construction Engineering ( } 3 \text { cr.) General Electives ( } 0-6 \text { credits): } \\
\text { Students may take elective courses of their selection to satisfy total program requirement } \\
\text { of } 162 \text { credit hours. }\end{array}$} \\
\hline
\end{tabular}

\section{7-conclusion:}

Sustainability should be applied in early years as a practical way in solving community problems, rather than limited it as a theoritical way only.The research concludes that msa university applied theoritical methods in sustainability more, $\mathrm{Hu}$ university apply practical sustainabiity in its case studies more than the theortical side. While AUC university apply it the theortical parrllel with the practical case studies,showing great success in the comparative analysis with the UIA assessment role.The article is an analytic survey is to assess the sustainability level of integration and implementation issues in the sustainable architectural curricula in Egypt. A set of additional recommendations is to assist in the process. These proposed recommendations are based on both the quantitative analysis of the sustainability teaching current status of in Egypt and the qualitative analysis of the survey. The extended analysis found that the results of the qualitative study correspond positively to the earlier quantitative results, hence cross-validating this study in egyptian 
universites. I summarise the main recommendations as follow: Creating sustainable methadology in architectural education, among architectural educators younger generation. Increase the awareness level of sustainability among educators with firstdegree qualifications. Revise the existing construct of sustainable design curriculum to inculcate sustainability awareness as a standard practice among lower year students in Egypt.In conclusion, we believe that architectural sustainable education has the potential to standard practice. So these recommendations as a guide in promoting egyptian architectural sustainability in education. Recommendations on how to promote 'sustainability' in Egyptian architectural education $45 \%$ of the respondents suggested that existing sustainable architectural curriculum in Egyptian universities to fully integrate it into all course works. This suggestion supports Wright's (2000) claim that for sustainability to succeed it must become the architectural education and practice. It must not be strongly identified with a particular area of architecture. to increase awareness among students and academics on sustainability. Government's step to develop more real-life sustainable an effective move towards enhancing public's awareness on the importance of sustainability in architectural education. And generate more environmental sustainability public awareness.

Table (7) shows Sustainable architecture questionnaire can be applied for implementing sustainability in architectural education according to UIA assessment. (UIA, 2017).

\begin{tabular}{|c|c|c|c|}
\hline Questionnaire & MSA & HU & AUC \\
\hline $\begin{array}{c}\text { The percentage of knowledge gained from } \\
\text { sustainability }\end{array}$ & $60 \%$ & $70 \%$ & $80 \%$ \\
\hline Variation in the assessment methods & $40 \%$ & $50 \%$ & $80 \%$ \\
\hline $\begin{array}{l}\text { Identify sustainable critical thinking in the } \\
\text { interaction between students. }\end{array}$ & $60 \%$ & $80 \%$ & $90 \%$ \\
\hline Identify real -life application & $50 \%$ & $90 \%$ & $90 \%$ \\
\hline Identify the extent of learning process & $60 \%$ & $70 \%$ & $90 \%$ \\
\hline $\begin{array}{l}\text { Illustrate the simulating of sustainability in each } \\
\text { course. }\end{array}$ & $60 \%$ & $60 \%$ & $80 \%$ \\
\hline $\begin{array}{l}\text { Teacher quality, teaching assessment evaluation } \\
\text { /teacher PD, Circulation development, } \mathrm{N}=\end{array}$ & $60 \%$ & $70 \%$ & $70 \%$ \\
\hline Curriculum development /update for students & $60 \%$ & $60 \%$ & $80 \%$ \\
\hline $\begin{array}{l}\text { Student recharge sustainable } \\
\text { programs/international exposure and collaboration }\end{array}$ & $50 \%$ & $80 \%$ & $80 \%$ \\
\hline \multicolumn{4}{|l|}{$\begin{array}{l}\text { Identify the percentage of } \mathrm{N} \text { including } \\
\text { international Course registration. }\end{array}$} \\
\hline \multicolumn{4}{|l|}{$\begin{array}{l}\text { What are the factors support to have best } \\
\text { sustainability teaching? }\end{array}$} \\
\hline \multicolumn{4}{|l|}{ Barriers facing sustainability in teaching courses } \\
\hline $\begin{array}{c}\text { idation of sustainable education of student concepts } \\
\text { Facilitation of sustainable education }\end{array}$ & $60 \%$ & $60 \%$ & $80 \%$ \\
\hline $\begin{array}{l}\text { Identifying sustainable outcomes for the } \\
\text { pedagogical energy consumption }\end{array}$ & $60 \%$ & $60 \%$ & $80 \%$ \\
\hline $\begin{array}{l}\text { The priority of sustainability to be teaches from } \\
\text { the beginning of studies to be holistic educational } \\
\text { output }\end{array}$ & $40 \%$ & $40 \%$ & $80 \%$ \\
\hline
\end{tabular}




\begin{tabular}{|c|c|c|c|}
\hline $\begin{array}{c}\text { comparative analysis for students Response } \\
\text { through years. }\end{array}$ & & & \\
\hline $\begin{array}{c}\text { What are the boundaries facing sustainability, and } \\
\text { how can we deal with it in education, and how to } \\
\text { solve it? }\end{array}$ & $60 \%$ & $40 \%$ & $30 \%$ \\
\hline $\begin{array}{c}\text { What are the adequate standards for the } \\
\text { sustainable architecture accreditation? }\end{array}$ & $50 \%$ & $60 \%$ & $80 \%$ \\
\hline $\begin{array}{c}\text { Design an accessible sustainable principal to be } \\
\text { applied in their design in an easy way }\end{array}$ & $50 \%$ & $60 \%$ & $80 \%$ \\
\hline Apply simulation for sustainability in verification & $60 \%$ & $60 \%$ & $80 \%$ \\
\hline $\begin{array}{c}\text { Applying sustainability in design assignment } \\
\text { Designing new pedagogical sustainable strategies } \\
\text { for future to be multi- disciplinary }\end{array}$ & $60 \%$ & $80 \%$ & $80 \%$ \\
\hline $\begin{array}{c}\text { Response to the challenging students, through } \\
\text { years, comparative analysis }\end{array}$ & $60 \%$ & $80 \%$ & $80 \%$ \\
\hline
\end{tabular}

\section{References}

1. Altomonte S (2009) Environmental education for sustainable architecture. Rev Eur Stud 1:12CrossRefGoogle Scholar

2. Altomonte S, Rutherford P, Wilson R (2014) Mapping the way forward: education for sustainability in architecture and urban design. Corp Soc Responsib Environ Mange 21:143-154CrossRefGoogle Scholar

3. Arkitektskolen Aarhus (2015) Focus areas [WWW Document]. Arkitektskolen Aarhus. http://aarch.dk/info/research/about-research/focus-areas. Accessed 15 Nov 16

4. Attoe W, Mugerauer R (1991) Excellent studio teaching in architecture. Stud High Educ 16:41-50 CrossRefGoogle Scholar

5. Brandt CB, Cennamo K, Douglas S, Vernon M, McGrath M, Reimer Y (2013) A theoretical framework for the studio as a learning environment. Int $\mathrm{J}$ Technol Des Educ 23:329-348CrossRefGoogle Scholar

6. Butera S, Astrup TF, Christensen (2015) Environmental impacts assessment of recycling of construction and demolition waste. Technical University of Denmark, Lyngby

7. Child D (2004) Psychology and the teacher. Continuum, LondonGoogle Scholar

8. Cole RJ (1980) Teaching experiments integrating theory and design. J Architect Educ 34:10-14 CrossRefGoogle Scholar

9. Cross N (1982) Designerly ways of knowing. Des Stud 3:221-227CrossRefGoogle $\underline{\text { Scholar }}$ 
10. EDUCATE (2012) Sustainable architectural education. University of Nottingham, White PaperGoogle Scholar

11. Farmer G (2013) Re-contextualising design: three ways of practicing sustainable architecture. arq: Architect Res Q 17:106-119 $\underline{\text { CrossRefGoogle Scholar }}$

12. Farmer G, Guy S (2009) Pragmatism and the ethics of sustainable architecture. Presented at the ethics and the built environment. University of Nottingham, Nottingham, pp 90-106 Google Scholar

13. Green LN, Bonollo E (2003) Studio-based teaching: history and advantages in the teaching of design. World Trans Eng Technol Educ 2:269-272Google Scholar

14. Haines C (2010) The role of the architect in sustainability education. J Sustain EducGoogle Scholar

15. Hartman $H$ (2011) The green building agenda is gathering pace but the task ahead is enormous. Architects' J 234:20 Google Scholar

16. Hillier B (1993) Specifically architectural theory: a partial account of the ascent from building as cultural transmission to architecture as theoretical concretion. Harvard Architect Rev 9:8-27Google Scholar

17. Hillier B (1998) Space is the machine: a configurational theory of architecture. Cambridge University Press, CambridgeGoogle Scholar

18. Kolb AY, Kolb DA (2005) Learning styles and learning spaces: enhancing experiential learning in higher education. Acad Manage Learn Educ 4:193212CrossRefGoogle Scholar

19. Lawson B (2004) Schemata, gambits and precedent: some factors in design expertise. Des Stud, Expertise in Des 25:443-457rossRefGoogle Scholar

20. Leroy P, Ligthart S, van den Bosch H, Ligthart S (2001) The role of project-based learning in the "Political and social sciences of the environment" curriculum at Nijmegen University. Int J of Sus in Higher Ed 2:8-20 Google Scholar

21. Levy A (1980) Total studio. J Architect Educ 34:29-32CrossRefGoogle Scholar

22. Mark L (2013) The green curriculum. Architects' J 238:78-82Google Scholar

23. Osmani M, Glass J, Price ADF (2008) Architects' perspectives on construction waste reduction by design. Waste Manag 28:1147-1158 CrossRefGoogle Scholar

24. Reinmuth G, Nielsen AG, Toft AE (2011) A beaux arts education for the 21st Century. Architectural Publisher BGoogle Scholar

25. Rutherford P, Wilson R (2006) Educating environmental awareness: creativity in integrated environmental design teaching. 40th Annual Conference of the Architectural Science Association ANZAScA. Presented at the Challenges for architectural science in changing climates. Adelaide School of Architecture, Adelaide, pp 261-269 Google Scholar

26. Sevaldson B (2012) GIGA-mapping [WWW Document]. Systems oriented design. http://www.systemsorienteddesign.net/index.php/giga-mapping. Accessed 12 Oct 2016 
27. Turkienicz B, Westphal E (2012) The cognitive studio: exercises in design learning. In: Shaping design teaching: explorations into the teaching of form. Aarborg University Press, pp 185-202Google Scholar

28. United Nations (2015) Transforming our World: The 2030 agenda for sustainable development (No. A/RES/70/1) Google Scholar

29. Unknown (2013) How to teach sustainable design. Architects' J 238:8385 Google Scholar

30. Unterrainer W (2015) Sustainability: an imperative for plurality and context. In: Sustainability: an imperative for plurality and context. Arkitektskolens Forlag, Aarhus, p 7Google Scholar

31. Van der Ryn S, Cowan S (1996) Ecological design. Island PressGoogle Scholar

32. Wenger E (2000) Communities of practice and social learning systems. Organization 7:225-246 CrossRefGoogle Scholar

33. UNESCO /UIA FOR ARCHITECTURAL EDUCATION (2017). Retrieved 11 June 2017, from https://www.uia-architectes.org/webApi/uploads/ressourcefile/178/charter2017en.pdf 